\title{
Market Orientation: Review and New Research Agenda
}

\author{
Bahman Hajipour \\ Faculty of economy and social science \\ Shahid Chamran University, Ahwaz, Iran \\ E-mail: Bhajipour@Gmail.com
}

Farajollah Rahimi

Faculty of economy and social science

Shahid Chamran University, Ahwaz, Iran

E-mail: rahimi2053@yahoo.com

Mohsen Hooshmand (Corresponding author)

Faculty of economy and social science

Shahid Chamran University, Ahwaz, Iran

Tel: 98-91-660-72260Ｅ-mail: mohsen.h84@Gmail.com

Received: Dec. 4, 2012

Accepted: December 18, 2012 Published: January 1, 2013

doi:10.5296/jmr.v5i1.2793

URL: http://dx.doi.org/10.5296/jmr.v5i1.2793

\begin{abstract}
In order to be successful in its business any firm needs an appropriate approach adoption with market. Market orientation is one of the most important strategic approaches. Market orientation means the true understanding of market, customers' demands, and adopting the true process to be responsiveness to the market's developments. In this research, by investigating the strategic approaches the marketing orientation is investigated totally. The Kohli-Jaworski, Narver-Slater, and Cadogan-Diamantopoulos's models are analyzed. Finally, by stating the similarities and differences of these models some suggestions for choosing the market orientation will be presented.
\end{abstract}

Keywords: Strategic Orientation, Market orientation, Business, Performance 


\section{Introduction}

Strategic orientation in business is among the realms which have got the attention of many managers, marketers, and academic researchers of the entrepreneurial field and business. The primary concept of orientation is based on the consultation and discussion and different subjects which covers different concepts (Hakala, 2011). The orientation word suggests a lasting or general direction of thought, inclination, and interest (Merriam Webster, 2009).

In the business and management literature orientation has been defined and interpreted to different meanings. Gatignon and Xuereb (1997) have defined strategic orientation as the principles which have influence on a firm's activities and also lead to kinds of behaviors by which performance, value, and consequently the life and the firm's preservation will be guaranteed. These principles affect and conduct the firm's activities permanently.

Some of the other researchers have called the orientation as a kind of adoption of organizational culture which is in interaction with environment (Nobel et al, 2002). In another definition, orientation is as the adaptable mechanisms which indicate the culture of a firm that can warranty its survival using that orientation (Braunscheidel and Suresh, 2009).

\section{Types of strategic orientations}

Although about the firm's orientation there are different types, with respect to the Hakala's classification four general orientations can be obtained and investigated. These four orientations are: market orientation, technology orientation, learning orientation, and entrepreneurial orientation (Hakala, 2011). In the first view other types such as innovation orientation, product orientation, customer orientation, and marketing orientation can be added to these four. Regarding this matter, it should be mentioned that in this classification the concept of market orientation has been considered widely and items such as customer orientation, concentration on the competitors, and marketing orientation have been included in too.

Market orientation and technology orientation have covered and analyzed the competitive issues appropriately. On the other side, two other groups of entrepreneurial orientation and learning orientation have shown the adaptation with organizational sources and the environment.

Another explanation about the approaches classification factors is about the factors that these approaches are affected by. Some of these orientations are more affected by external and some are affected more by internal factors. Although it should be mentioned that these kinds of classifications are not absolute and are merely appropriate for doing the research projects (Hakala, 2011). However, in real world all of these approaches are tied with together and are often hard to be separated when there is not a line between them. Furthermore, even if in the real world such a separation could be done not only because of the impossibility of operationalization, but also because it has viewed the business world from only one aspect it is not efficient and useful. 


\subsection{Entrepreneurial orientation}

Entrepreneurial orientation is a strategic approach which, specifically from the viewpoint of entrepreneurship in the firm, concentrates on the firm's strategies and conducts those (Bhuian et al, 2005). In the investigation of entrepreneurial orientation the inclination to risk taking, innovation and hyperactivity in the field of business are defined as the canonical parts of this approach (Miller, 1983; Covin\&Slevin, 1989). Lumpkin and Dess(1996) have defined the concept of entrepreneurship as the orientation to competition and behaving in an invasive way, and also tend to independency autonomy in the different units of the organization has been counted as one of the aspects towards this orientation. The central core which the entrepreneurial orientation emphasizes on is the organization activity basied on the proposed matters (competitive orientation and behave invasively), and also emphasizes that in the global market and the high level of competition an organization with such an orientation can be active in such an environment in a better way and regulate its reactions and responses (Covin\&Slevin, 1989; Hakala, 2011).

With an entrepreneurial orientation, organizations aim to change the environment and reshape it and try to use uncertain sources, possible opportunities, and dedicate the sources to such cases. These kinds of organizations by making the ideas as patterns, creating the innovations and also a courageous presence in different and new markets try to lead the market and are always seeking to control the market's atmosphere based on their own interests. The entrepreneurial oriented organizations mostly prefer the activities based on the reaction and attempt to leave others behind and always care about customers' present needs and demands, and anticipate the future needs and directing these demands and needs are the targets (Hult et al, 2004; Keh et al, 2007; Wiklund\& Shepherd, 2005).

\subsection{Market orientation}

It is a long time that market orientation is the core of the marketing literature and also is considered as the activity and the organizational culture which concentrates on the performance and market activities quite sensible. In the market orientation the market knowledge and information and using it plays a crucial role in getting competitive advantage (Deshpandé, et al, 1993; Kohli\&Jaworski, 1990; Narver\&Slater, 1990).

\subsection{Technology orientation}

Technology orientation and specifically the same product and innovation orientation (Grinstein, 2008) point to the firm's inclination to introduce or use the new technology in order to new product or service production (Hult et al, 2004). Gatignon and Xuereb (1997) claim that establishing the superior value for customer and consequently the long term success of a firm through innovation and technological solutions in products, services, and producing processes is possible. Investment in new technologies, in addition to improving the firm for services and products presentation for customers' current needs, assumes the access to new markets and guarantees it consequently. On the other hand, the possibility of confrontation with severe deep changes is provided for the firm (Christiansen \& Bower, 
1996). Finally, a lot of research have emphasized on the effect of technology orientation on the business improvement by using technological solutions (Day, 1999; Hakala, 2011).

\subsection{Learning orientation}

From the Huber's viewpoint (1991) learning is to establish and get the new knowledge in order to have a capability which the organization let this move with the purpose of affecting the behavior and activity. In other words, learning has been followed by new behaviors and led to value creation (Argris\& Sean, 1978 quoted by Hakala, 2011). Learning orientation is the organization inclination to create and use of knowledge (Sinkula et al, 1997) to achieve the stable competitive advantage (Calantone et al, 2002).

Sinkula et al (1997) knows the organizational learning orientation as the subject of establishing common perspective, open mind, and obligation for learning in inter-organization relationships. In the first view with respect to the knowledge acquisition from the market and using it in learning orientation this is possible that learning orientation of the environment affects the market and technology orientation (Calantone et al, 2002). Creating the new technologies, products, and processes includes specific forms of learning. On the other side, during the research on learning orientation the consumer, competitors, and technology are rarely at the center of the attention (Sinkula et al, 1997).

In relation to the similarity of this approach with entrepreneurial orientation, it should be mentioned that the entrepreneurial orientation suggests the relationships and organization's relations change with the environment through reallocating the used sources in developing the market and product, while in the learning orientation understanding or the ability to understand the causes of the changes in the organization's behaviors is included generally (Hakala, 2011).

According to the mentioned subjects market orientation is chosen as the selected orientation of the research.

\subsection{Reason of selecting the strategic market orientation and its importance}

For many years, research on market orientation has had the main role in forming the thought and attitude towards the marketing literature (Helfert et al, 2001 quoted by Shepherd, 2011). Market orientation and the factors which affect and are affected by have been investigated and examined in many research. In relation to this issue it can be referred to cases such as new product development (Shepherd, 2011), selling increasing, income increasing, the high level of employees' satisfaction, commitment, commitment and trust, service presentation to the costumer (Narver\& Slater, 1993), privileged firm’s performance (Kohli\&Jaworski, 1993), and the best congruence of market orientation with respect to innovation, the product advantage and inter-segment team working (Atuahene-Gima, 1996). On the other hand, market orientation conducts the firm to more innovation and guides its success (Farrell \&Oczkowski, 1997 quoted by Sheppard, 2011).

Other important subjects on this field are the comprehensive views on implementing and executing the market orientation at the organization level. In this field Greenly (1985, a \& b) 
states that if the firm can have a comprehensive and universal look on the market orientation and find it in all of the levels of the organization, it will have a better performance than executing a part of it.

\section{Terminology and definition of the market orientation}

Although in relation to definition and function of the market orientation discussions have been proposed, in the beginning of the 80s and 90s market orientation framework was recognized and introduced (Shepherd, 2011; Day, 1994). However, some of the researchers have referred the root of the market orientation concept to Adam Smith and his well-known book, Nations' Wealth. Nonetheless, most of the researchers of the marketing have referred the root of the market orientation to Peter Drucker (1954) (Shepherd, 2011). In the beginning of 90s, also market orientation was equal to the marketing concept (Shapiro, 1988; Webster, 1988).

Different definitions of market orientation have been proposed and many researchers have stated their opinions.

D1: Market orientation-a set of beliefs that puts the customer's interests first (Deshpandé, Farley, and Webster Jr., 1993).

D2: Market orientation-the ability of the organization to generate, disseminate, and use superior information about customers and competitors (Kohli and Jaworski, 1990).

D3: Market orientation-the coordinated application of inter-functional resources to the creation of superior customer value (Narver and Slater, 1990; Shapiro, 1988b).

D4: Market orientation-is the business culture that most effectively and efficiently creates superior value for customers (Narver and Slater, 1990).

\subsection{Relationship between market orientation and the marketing concept}

In a research Deng and Dart (1994) tried to mix the views of Kohli and Jaworski (1990) and Narver and Slater (1990) that in their research market orientation was treated the market orientation as implementing the trade and business philosophy like the marketing concept.

These two define the market orientation and marketing as following:

Market orientation-the generation of appropriate market intelligence pertaining to current and future customer needs and the relative abilities of competitive entities to satisfy these needs; the integration and dissemination of such intelligence across departments; and the coordinated design and execution of the organizations strategic response to market opportunities.

Marketing concept-a business philosophy that holds that long-term profitability is best achieved by focusing coordinated activities of the organization toward satisfying the needs of particular market segments(s).

It is observed in these definitions that market orientation is an operational extension of marketing philosophy. Day (1994) notes that to achieve the market orientation the marketing 
capabilities should be implemented and executed in organization better than ever. These capabilities should be able to cover the following aspects: feeling the market opportunities, communication with customers, the feel of competition, customer service, seeking the technology and try to use it, developing the products and presenting the new versions and new services, human and financial sources management, organizational communications, and establishing the general and integrated strategy in organization.

The final investigation of these two views leads to this matter that the long term value for the customers finally results in the firm's benefit. This issue forms the marketing basic philosophy and is the main motivation for a market oriented firm (Sheppard, 2011).

\subsection{Market orientation classification}

Market orientation has been classified from different viewpoints (Sheppard, 2011). In this field the proposed classification by Cervera et al (2001) and Lafferty and Hult (2001) can be noted.

In the classification by Cervera et al (2001), four approaches in relation to market orientation have been obtained. These approaches are: cultural-philosophical, orientations based on the customers and competitors, inter-segment cooperation, market data processing, and sources and capabilities theories.

In another classification, Lafferty and Hult (2001) have proposed five different views in relation to market orientation. These five views are: decision making, market intelligence, behaviors based on the culture, focusing on strategic marketing, and customer orientation.

\subsection{Relationship between market orientation and marketing orientation}

In using the appropriate word for this concept, most of the researchers are unanimous that market orientation is a better phrase than marketing orientation. Kohli and Jaworski (1990) propose three reasons for this selection. First, by confirming the Shapiro's opinion (1988) state that market orientation specifically indicates the comprehensiveness of the process and merely the marketing segment is not involved in this subject. By using this word, in addition to the marketing segment other segments are also involved in market intelligent data collection at the right time and appropriately. Thus, using the market orientation phrase obviates this misunderstanding.

Second, the market orientation phrase does not establish the political, authoritative, and dominant view for the marketing segment in the organization. This word regulates the marketing dominance in organization and makes all of the existed segments of the organization responsible for competition and the dominant market and its consequents.

Third, the view on market (customers and effective factors on them) bans the researcher to be limited prospectively in the field of marketing factors and considers other factors for him/her (Park \&Zaltman, 1989 quoted by Kohli\&Jaworski, 1990). 


\section{Common views on the field of market orientation}

Considering the literature relevant to market orientation it is seen that three models are noted more than other models by researchers. These three models are: Kohli and Jaworski's (1990), Narver and Slater's (1990), and Cadogan and Diamantopolous's (1995). In the following each of these 3 models will be investigated and analyzed.

\subsection{Kohli and Jaworski's model proposed in 1990}

Kohli and Jaworski started their research question with proposing this problem that implementing the marketing concept has not been accurately done in research text. These researchers suggest that the marketing concept is the canonical part of marketing systems. Investigating the research literature they suggested three features to respond to the market orientation implementing: 1. having a clear definition, 2. enough richness and having the support about theoretical discussions and, 3. experimental findings indicating these definitions. The investigations of these researchers showed that despite of the lots of attempts such as Deshpandé and Webster (1989), the weakness in a clear and correct definition, lack of accuracy in measuring and theoretical discussions and also experimental findings irrelevant to theoretical literature in these researches, showed the shortcomings clearly in this area. In these researches enough attention has not been paid to the content factors forming the market orientation congruent to business. These researchers by proposing these issues have stated that their goal is an accurate drawing of market orientation system aspects, operational construction definition, proposing a list of statements and building a comprehensive framework for conducting the future research. The research of these two researchers was done based on the interviews with managers and testing the obtained results from these interviews.

Kohli and Jaworski (1990) extracted the three main concepts based on the McNamara's definition of market. McNamara (1972) in a wide definition on marketing concept, calls it a philosophy of business management which the firm has accepted its totality and commitment to the customer orientation, profitability and identifying the important role of the marketing in communications related to market needs to other important segments of the organizations (Kohli\&Jaworski, 1990). Three concepts which Kohli and Jaworski extracted are: customer focus, coordinated marketing, and profitability.

\subsubsection{Customer focus}

By interviewing the managers Kohli and Jaworski (1990) found that in addition to be agree with the traditional views they consider the attention to the information and getting it in business as important. Managers suggest that market orientation based on the intelligent data collection more efficient than data collection in an irregular and unsystematic way. Also the market intelligence, considering the externalizing factors of the market (such as competition and rule) which are effective on the preferences and customers' ideas and is the current and future needs of the customers. 


\section{Macrothink}

Journal of Management Research

ISSN 1941-899X

2013, Vol. 5, No. 1

\subsubsection{Coordinated marketing}

Despite the low attention of the interviewees to coordinated marketing, Kohli and Jaworski suggest that responding to the market issues is not merely the work of the marketing and its segment and all segments are responsible for this issue.

\subsubsection{Profitability}

In investigating the managers' views profitability was one of the main parts of the market orientation and they consider a more important position for profitability. This subject is according to the findings of Levitt (1969) (quoted by Kohli and Jaworski, 1990) which they profitability is called the main goal of market orientation.

Accordingly, the findings show that market orientation includes three factors. These three factors are:

1. One or more segments involved in identification and understanding the current and future needs of the customers and effective factors on them.

2. Sharing and dissemination this understanding among all of the segments.

3. Designing, implementing, and responding of all he segments to customers' needs and demands

In other words, market orientation pointing to the data establishment and monitoring it at the organizational level and also its dissemination and responding to the market collected data.

\subsubsection{Intelligence generation}

The commencing point of the market orientation is the intelligent towards the market. This concept is more extensive than the current needs identification, stated and available to the customers. This concept points to the externalizing effective factors analysis on the needs, demands and preferences of the customers. For example, it can be referred to the government and competitive effective rules on these needs. On the other hand, it is pointed to the positional analysis which has led to the change in industries and these needs and demands are affected by. Another hidden issue in this concept is the permanent tracing of competitors and recognizing the way they affect the customers. Investigation and the environmental monitoring of the activities on the market levels is another effective action to intelligence towards the market.

\subsubsection{Intelligence dissemination}

In the Kohli and Jaworski's research, the quick and efficient responding to the market needs requires comprehensive coordination and cooperation of all the segments of the organization. For example, one can refer to the coordination among the relevant segments to design and create new product, build and update the organization productions, procurement for the organization segments, investment to create and develop the activities and etc. Some managers emphasize on the dissemination through the periodical brochures in order to quick and identical understanding of market in their organization. These findings are in accordance 


\section{Macrothink}

with the research literature of organization conduct in relation to understanding the market and marketing responsibility (Levitt, 1969). To this aim, marketing and marketers play an important role in this area. Although it should not be thought that intelligent dissemination of information is merely the work of the marketing, other segments should cooperate in this matter (Kohli\&Jaworski, 1990). On the other hand intelligent dissemination of information in the organization is like the flow of water dependent to its origin which is the spring. Finally, the intelligent dissemination of information is important in this way that provides the common bases to concentrate different segments' activities in the organization.

\subsubsection{Responsiveness}

The third element of the market orientation is the appropriate responding to the market obtained data. If an organization has obtained appropriate data about the market and disseminate it well enough in the organization, but yet does not move toward the responding, the market orientation is not settled down and a success from the side of the market orientation is not obtained for the organization.

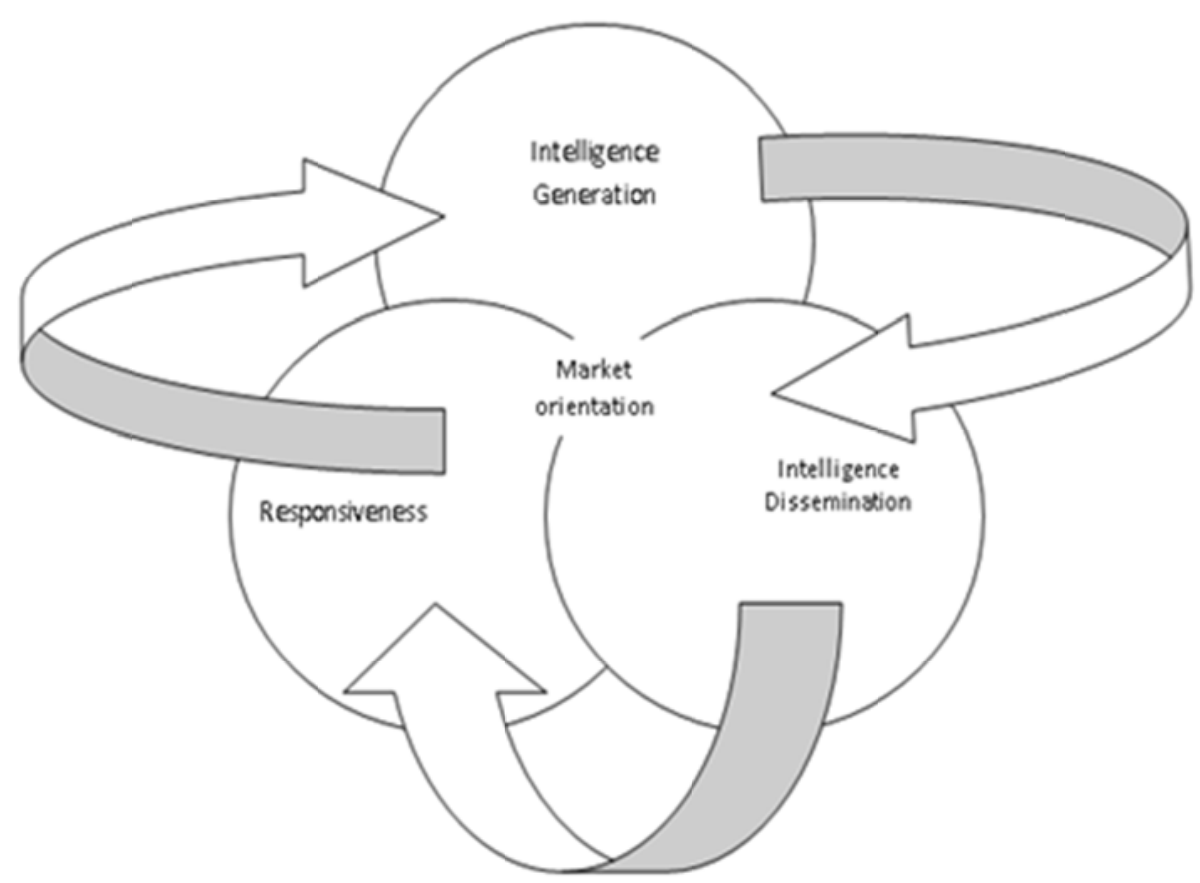

Figure 1. Kohli\&Jawoerski model

The field finding show that responding to the market data, is a kind of target market acquiring which by using products designing and service presentation responds to the current needs and takes the last step towards the production, preferment, and product distribution according to the consumer demand. It is clear cut that all the segments and not only the marketing are responsible in this field. 


\subsection{The proposed model by Narver and Slater in 1990}

Narver and Slater (1990) started their model with respect to the weakness of measuring for the performance fields of business in the realm of market orientation despite of the marketing managers' emphasis and the academic researchers on this matter. These researchers suggest that the heart strategy and modern marketing is truly the market orientation. In the field of business, marketers are always looking for a solution for measuring their success in the field of settling and implementing the market orientation, but they have not gotten an appropriate answer. By proposing this problem, Narver and Slater (1990) put their research concentration on the business performance and its prequel that is the firm's privileged performance. These cases can be achieved by acquiring the stable competitive advantage (Porter, 1385; Aker, 1386). By acquiring the stable competitive advantage one can create a privileged value for customers. The logic of the stable competitive advantage refers to this matter that the vendee with investigating and buying the $\mathrm{X}$ product expect that the anticipated value of that buying (customer's need and demand obviation) goes beyond any suggestion and alternative of this product.

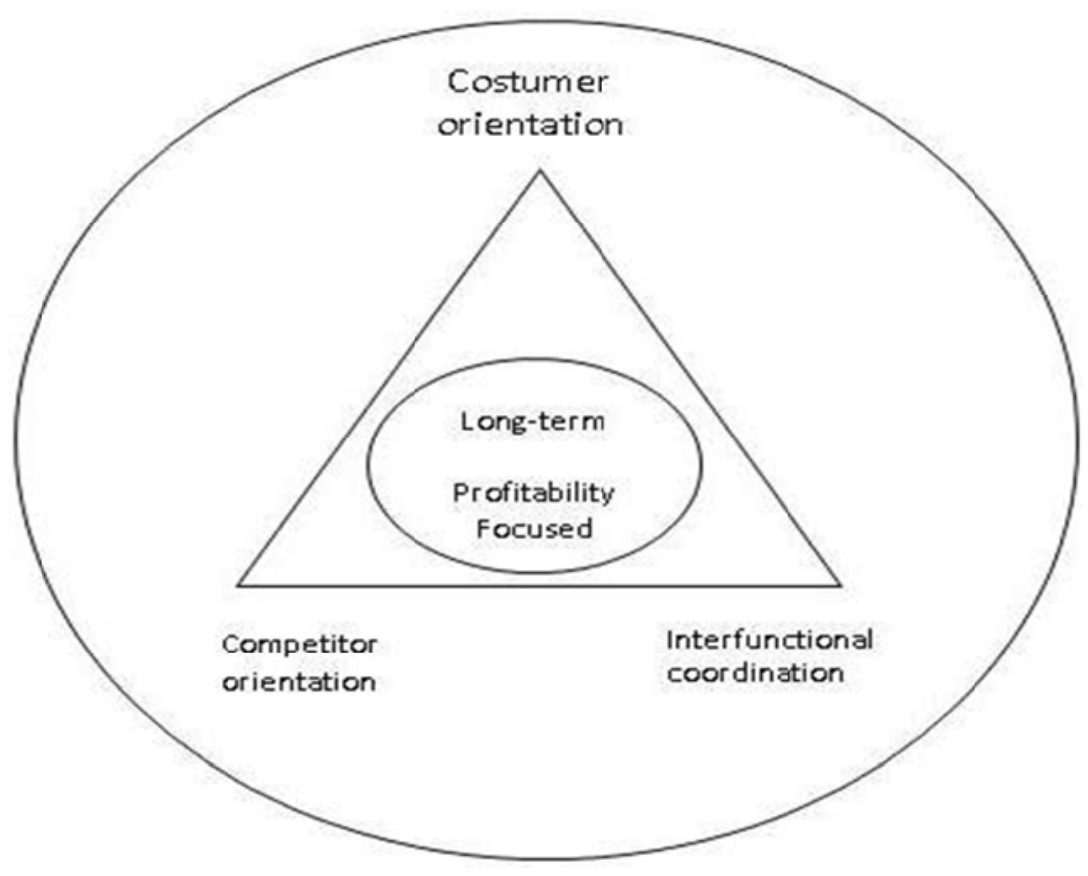

Figure 2. Narver\&Slater Model

Any seller has myriad opportunities to create value added for customers’ procurement with increasing the profits and interests. In order to achieve the privileged value for the customers and attending to the stable competitive advantage a commercial organization should be able to include a culture in itself which leads to the creative behaviors and be indicative of competitive advantage.

According to the definition proposed by Narver and Slater (1990) market orientation is an organizational culture (Deshpandé and Webster, 1989) which in an efficient and effective 
way paves the way for creating the privileged value added for vendees based on the privileged performance for business will be obtained (Aker, 1386; Kohli and Jaworski, 1990).

The market oriented seller creates many sources for stable competitive advantage by using numerous tools for creating the value added for vendees and also by different ways of cost decreasing-profit (Aker, 1386; Porter, 1985; Hall, 1980). Therefore, a market oriented organization has tested its sources alternatively to create the stable competitive advantage to be able to choose or establish the most effective tools in creating the stable competitive advantage in the current and future target markets among them. On the other hand, in order to maximizing their long-term performance, the firms should identify or improve their bilateral or multilateral relationships with each other.

Narver and Slater (1990) have discussed and obtained three behavioral elements including customer orientation, competitive orientation, and coordination of inter-segment and also 2 criteria of decision making including the long-term concentration and profitability in relation to market orientation.

Customer and competitive orientation include all of the activities which are done in order to data collection relevant to vendees and competitors in the target market and also disseminating that data in all of the parts of the organization. The third element, coordination of inter-functional, typically includes the activities beyond the marketing segment and aim to create the privileged value for vendees. Totally, each of the 3 behavioral market orientation elements of the Narver and Slater, are the comprehensive activities to acquire and disseminate the acquired data and create the privileged value for customers.

\subsubsection{Customer orientation}

Narver and Slater note that in relation to the customer the organization should know the identification of the customer's chain value as its own goal in addition to attending the current customer's values (Day \&Wensley, 1988). On the other hand, considering all of the aspects the external and internal factors and considering the market dynamics the organization should take the action to identify the customer and focus on it.

Based on the Narver and Slater (1990) the seller creates the value for vendee only in two ways: increasing the vendees interests toward their expenditures and the other, decreasing the vendees' expenditures toward their interests.

A seller should be able to consider all of the aspects whether effective political or economic aspects on the customers decisions and preferences and also identify and follow the relevant ways. With such a comprehensive view, the sellers can predict current and future needs and demands of the vendees and consequently take steps to verify those needs and demands.

\subsubsection{Competitor orientation}

In the Narver and Slater (1990), literature competitive orientation means that the seller investigates and consults the weaknesses and strengths of the competitors in short term, and the capabilities and their strategies at the present and future time in long-term period. 
Paralleling the customer analysis, the competitor analysis also includes investigating the current and future competitors and the total set of used technologies to satisfy the current and future customers by the seller (Levitt, 1960, quoted by Narver and Slater, 1990).

\subsubsection{Inter-functional coordination}

The third element is the inter-functional coordination. Any part in the vendees' value chain can be an opportunity for the seller to establish a firm. Thus, any person in any segment of the organization can help this value creating process. Accordingly, these attempts are the results of all segments cooperation and they do not merely include a particular set or unique segment.

At the decision making aspects also the recommendation always has been this that the long-term aspect should be considered and investigated or in other words three proposed behavioral elements in long-term should be implemented and executed. Finally, the final goal of the market orientation is the profitability and/or the economic value (Narver\& Slater, 1990).

\subsection{Cadogan and Diamantopoulos model (1995)}

Cadogan and Diamantopoulos (1995) started their approach by considering a shortcoming existed in the market orientation field in the international arena. These two by investigating the prior texts and enumerating them have introduced the internationalization element in the market orientation. In one hand, with combining 2 views of Kohli-Jaworski and Narver-Slater they achieved a new and integrated combination, and on the other hand by criticizing these two views and the overlapping existence and of course vagueness have investigated these factors more precisely.

In table 2-3, Cadogan and Diamantopoulos (1995), detailed and comparative investigation of the two Kohli-Jaworski's and Narver-Slater models, examples related to each one has been illustrated (Cadogan \& Diamantopoulos, 1995). 

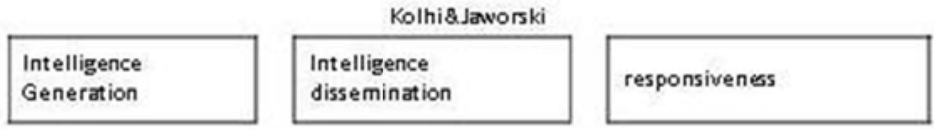

Narver\&SIater
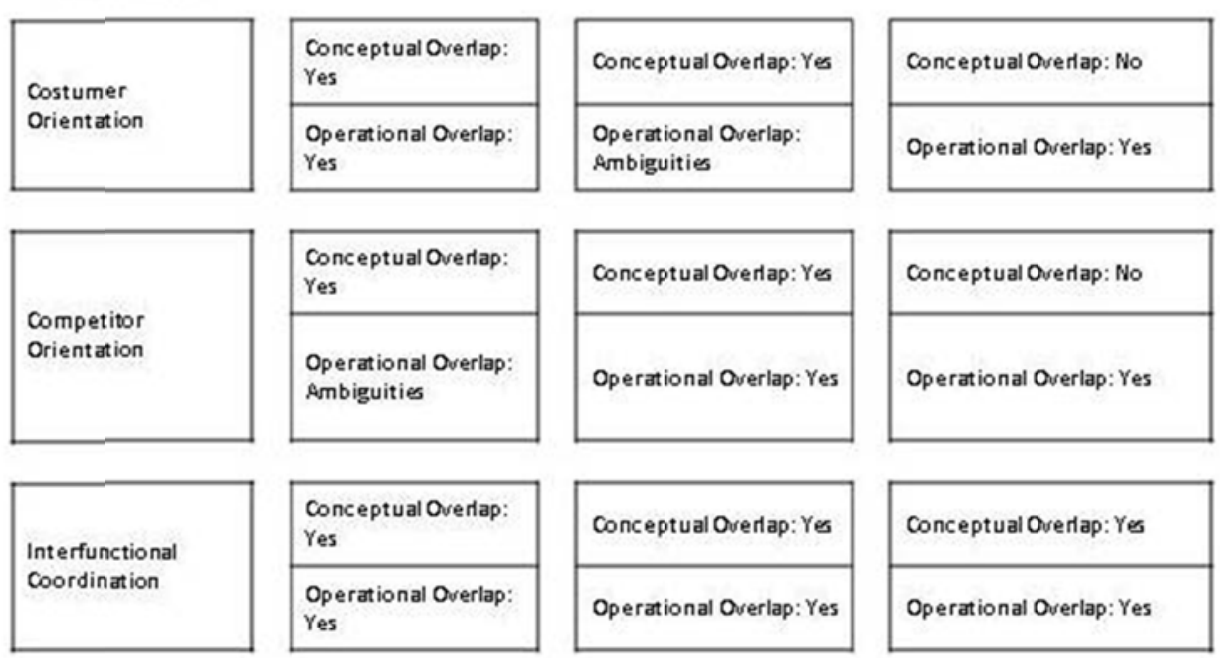

Interfunctional dependency

Exogenous Market influences

Informal/formal dissemination

Response

design/implement ation

Figure 3. Narver\&Slater and Kohli\&Jaworski - Conceptual Overlaps in the Market orientation Construct

At the operational level, there is a great amount of the overlapping between two approaches. Narver-Slater' model has applied vague and unclear gauges and in some cases it has not the intended clearance. 


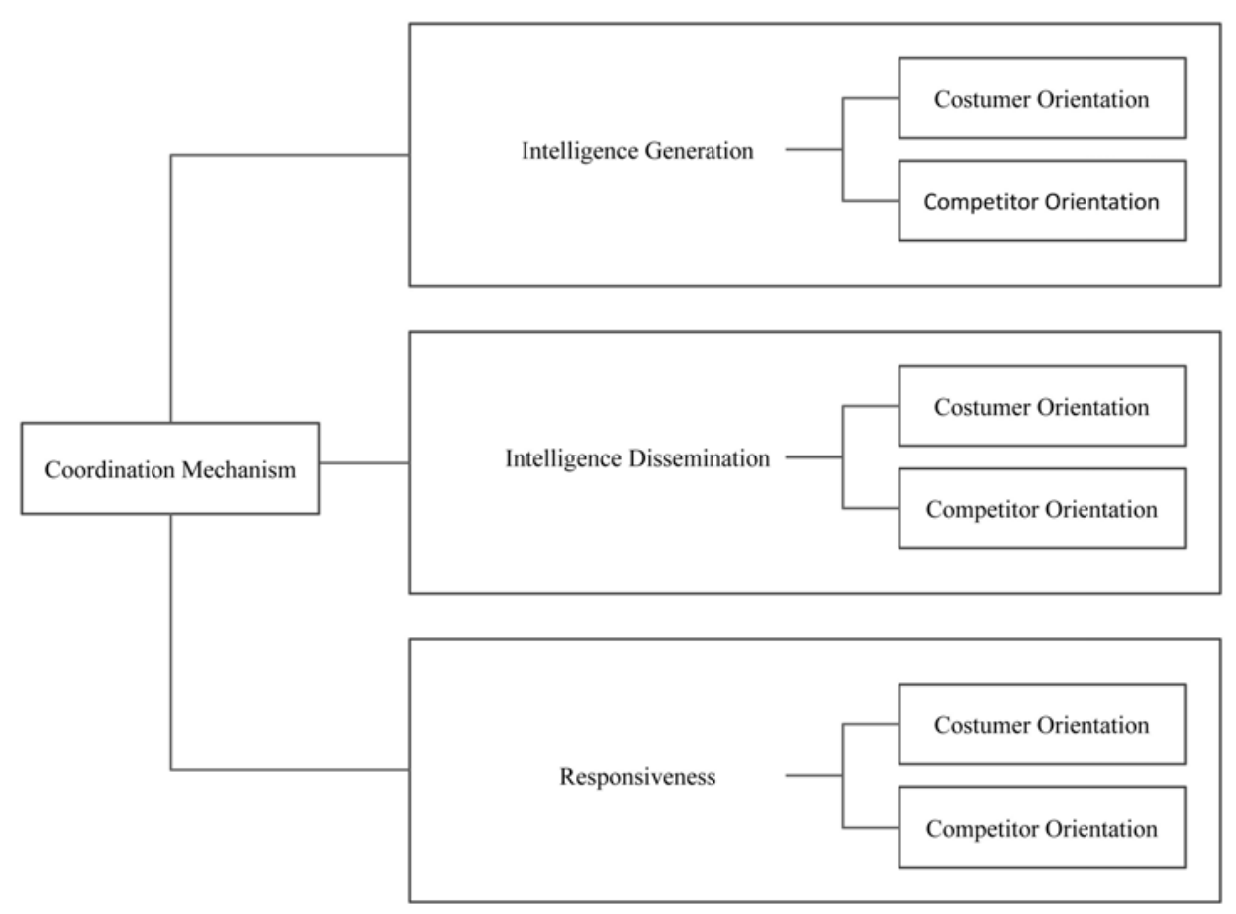

Figure 4. Market orientation reconceptualized

By combining these two views Cadogan and Diamantopolous has introduced competitive orientation and customer orientation into the three market orientation elements of Kohli-Jaworski, has discussed, and investigated them specifically. On the other hand, based on the coordination mechanism they have brought the Kohli-Jaworski 3 elements with each other and prevent from their overlapping. In addition, two researchers have introduced the international aspect in their model and investigated it in relation with market orientation. 


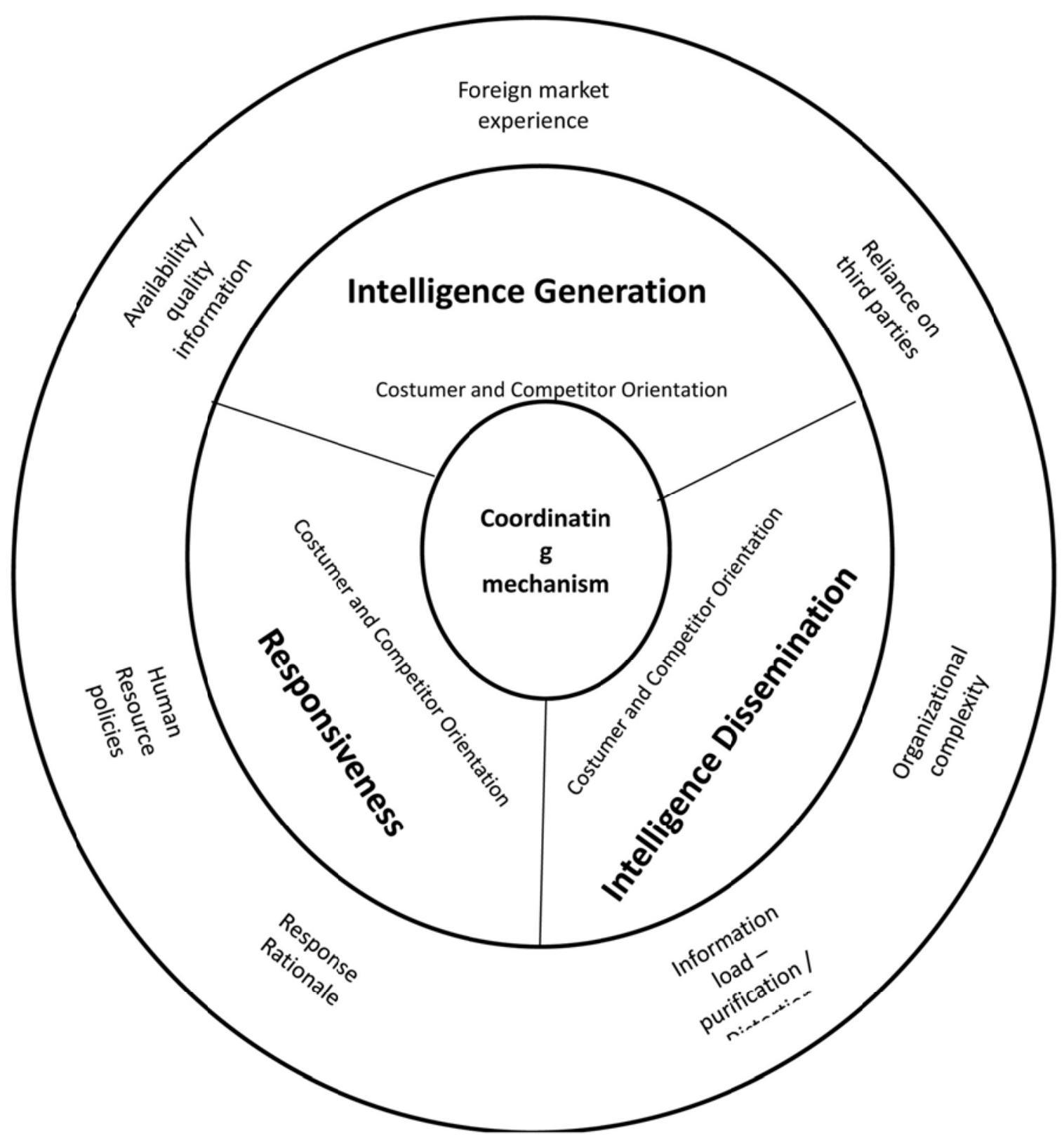

Figure 5. Market orientation in an international setting

The firms in the international environment are faced with more challenges than in their interior environment. These challenges can be considered in the fields of legal standards, political subjects, economic situations, technological complexities, social forces, and also the distribution structures and the cultural and geographical differences. Each of these cases can have great effect on the concept and performance of the marketing (Cadogan\&Diamantopolous, 1995).

Because of the complexity of the international environment, the requirement for more data needs create problems and challenges which the firm is not faced with at the interior level. 
4.3.1 adaptation and investigation of the international aspect with Kohli-Jaworski's model

Internationalization in relation to the triple factors of market orientation of Kohli-Jaworski has created more complexities and challenges for the firms.

Table 1. Adaptation of the Cadogan-Diamantopolous with Kohli-Jaworski”s model

\begin{tabular}{|l|l|}
\hline Intelligence Generation & $\begin{array}{l}\text { Foreign ninrket experience, Availability and quality of information, Reliarrce otz } \\
\text { third parties }\end{array}$ \\
\hline $\begin{array}{l}\text { Intelligence } \\
\text { Dissemination }\end{array}$ & Information load, purification and distortion, organization complexity \\
\hline Responsiveness & Rationale underlying response formulation, human resource policies \\
\hline
\end{tabular}

\section{Discussion}

As the proposed discussions show both models of Kohli-Jaworski and Narver-Slater have some differences and similarities. The common interfaces and their overlapping have been expressed in the research of Cadogan and Diamantopolous (1995).

But about the different interfaces it can be pointed to the most important one which says that the Kohli-Jaworski's model is of the organizational kind which considers the totality of the organization more than ever. In the whole research of Kohli-Jaworski (1990) these two have investigated the firm and organization and generally their strategies while in Narver-Slater (1990) despite of considering the importance of the organization and to some extent its nomination to behavioral model of the organization; they have a kind of segment view to the market orientation subject. This subject can be deducted from the inter-segment coordination variable presentation too. In the Kohli-Jaworski's model, from the very beginning the whole organization has been involved and progressed step by step, while in the Narver-Slater's model and the presented literature by them the crucial role for the sale forces has been considered. It can be suggested that the inter-segment coordination variable presentation has been in the totality of this model because of its imperfection. It is emphasized in the following that in both models the implementation and execution of the market orientation in the whole organization have been pointed out.

\section{Reasons of not using the Cadogan and Diamantopolous's model (1996)}

The most important reason of not using this model is its complexity, in a way that some of the research (Rose and Shoham, 2002) because of the lack of trust in getting the appropriate reliability did not use this model.

On the other hand, the main feature of a model is in simplifying the facts to better understanding of the problem which to reach to this goal some of the features for understanding are removed. However, in Cadogan and Diamantopolous' model (1995) the complexity of the model has violated this main feature of any model. 


\section{Macrothink}

The third reason is the prevalence of the Kohli-Jaworski's and Narver-Slater's model in the marketing research. For this issue one can refer to the Google scholar data base. The number of visits over the Kohli-Jaworski's research was 5075 and for Narver-Slater was 5100, while the Cadogan-Diamantopolous's model has had 235 visits. This matter has indicated the more acceptability and congruency of these models for research.

\section{Conclusion}

In this research with a comprehensive investigation has investigated the superior models in the area of marketing administration.

If a firm intends to enter into a new and unfamiliar market in one hand, and has appropriate and strong organization and foundation on the other, the Kohli-Jaworski's model is an appropriate model for it. The cause of this selection is about the type of the model. In the Kohli-Jaworski's model with establishing the extensive and appropriate information, the widely data collection of the market is done. By disseminating that information at the organization level, the kind of responding to the customers' needs and demands is investigated. With such actions, the best responding process to these needs is designed and presented.

Related to Narver-Slater model if a firm has the conditions and the size of SME and intends to enter into the current market to get more shares of the market this could be searched through the customers and competitors' identification present in the market. In this model in order to investigate the current and future share, customers' needs, seeking and the current competitors are analyzed. With regular meetings and coordination in the organization, the coordination in all of the organization segments is implemented. This shows the need of organization to cooperation and coordination.

If a firm intends to enter into the exporting market arena, the complex Cadogan-Diamantopolous's model is the appropriate model for it. However, enough attention should be paid to the complexity of the model and the variety of the variables.

Among the suggestions which are considerable in this field is that in other research in order to experimental confirmation of the above-mentioned suggestions the experimental research should be done.

\section{References}

Atuahene-Gima, K. (1996). Market Orientation and Innovation. Journal of Business Research, 35, 93- 103. http://dx.doi.org/10.1016/0148-2963(95)00051-8

Bhuian, S., Menguc, B., \& Bell, S. (2005). Just entrepreneurial enough: the moderating effect of entrepreneurship on the relationship between market orientation and performance. Journal of Business Research, 58, 9-17. http://dx.doi.org/10.1016/S0148-2963(03)00074-2

Braunscheidel, M., \& Suresh, N. (2009). The organizational antecedents of a firm's supply chain agility for risk mitigation and response. Journal of Operations Management, 27, 119-140. http://dx.doi.org/10.1016/j.jom.2008.09.006 


\section{Macrothink Institute ${ }^{\mathrm{TM}}$}

Cadogan, J. W., \& Diamantopoulos, A. (1995). Narver and Slater, Kohli and Jaworski and the market orientation construct: integration and internationalization. Journal of Strategic Marketing, 3(1), 41-60. http://dx.doi.org/10.1080/09652549500000003

Calantone, R., Cavusgil, S., \& Zhao, Y. (2002). Learning orientation, firm innovation capability, and firm performance. Industrial Marketing Management, 31, 515-524. http://dx.doi.org/10.1016/S0019-8501(01)00203-6

Cervera, A., Molla, A., \& Sanchez, M. (2001). Antecedents and Consequences of market Orientation in Public Organizations. European Journal of Marketing, 35(11/12), 1259-1288 .http://dx.doi.org/10.1108/EUM0000000006476

Christensen, C., \& Bower, J. (1996). Customer power, strategic investment, and the failure of leading firms. Strategic Management Journal, 17, 197-218. http://dx.doi.org/10.1002/(SICI)1097-0266(199603)17:3<197::AID-SMJ804>3.0.CO;2-U

Covin, J., \& Slevin, D. (1989). Strategic management of small firms in hostile and benign $\begin{array}{llll}\text { environments. } \quad \text { Strategic } \quad \text { Management } & \text { Journa, } & \text { 10, }\end{array}$ http://dx.doi.org/10.1002/smj.4250100107

Day, G. (1994). Misconceptions about market orientation. Journal of Market Focused Management, 4, 5-16.

Day, G. S., \& Wensley, R. (1988). Assessing Advantage: A Framework for Diagnosing Competitive Superiority. Journal of Marketing, 52(2), 1-20. http://dx.doi.org/10.2307/1251261

Deng, S., \& Dart, J. (1994). Measuring Market Orientation: A Multi-Factor, Multi-Item Approach. Journal of Marketing Management, $10(8), \quad 725-742$. http://dx.doi.org/10.1080/0267257X.1994.9964318

Deshpandé, R., Farley, J., \& Webster, F. J. (1993). Corporate culture, customer orientation and innovativeness in Japanese firms: a quadrad analysis. Journal of Marketing, 57, 23-37. http://dx.doi.org/10.2307/1252055

Gatignon, H., \& Xuereb, J. (1997). Strategic orientation of the firm and new product performance. Journal of Marketing Research, 34, 77-90.http://dx.doi.org/10.2307/3152066

Greenley, G. E. (1995b). Forms of Market Orientation in UK Companies. Journal of Management Studies, 32(1), 47-66. http://dx.doi.org/10.1111/j.1467-6486.1995.tb00645.x

Greenley, G. E. (1995a). Market Orientation and Company Performance: Empirical Evidence from UK Companies. British Journal of Management, 6, 1-13. http://dx.doi.org/10.1111/j.1467-8551.1995.tb00082.x

Grinstein, A. (2008). The relationships between market orientation and alternative strategic orientations: a metaanalysis. European Journal of Marketing, 42, 115-134. http://dx.doi.org/10.1108/03090560810840934 
Hakala, H. (2011). Strategic Orientations in Management Literature: Three Approaches to Understanding the Interaction between Market, Technology, Entrepreneurial and Learning Orientations. International Journal of Management Reviews, 13, 199-217. http://dx.doi.org/10.1111/j.1468-2370.2010.00292.x

Huber, G. (1991). Organizational learning: the contributing processes and the literatures. Organization Science, 2, 88-115.http://dx.doi.org/10.1287/orsc.2.1.88

Hult, G., Hurley, R., \& Knight, G. (2004). Innovativeness: its antecedents and impact on business performance. Industrial Marketing Management, 33, 429-438. http://dx.doi.org/10.1016/j.indmarman.2003.08.015

Keh, H., Nguyen, T., \& Ng, H. (2007). The effects of entrepreneurial orientation and marketing information on the performance of SMEs. Journal of Business Venturing, 22, 592-611. http://dx.doi.org/10.1016/j.jbusvent.2006.05.003

Kohli, A., \& Jaworski, B. (1990). Market orientation: the construct, research propositions, and managerial implications. Journal of Marketing, 54, 1-18. http://dx.doi.org/10.2307/1251866

Lafferty, B. A., \& Hult, G. T. (2001). A Synthesis of Contemporary Market Orientation Perspectives. European Journal of Marketing, 35(1/2), 92-109. http://dx.doi.org/10.1108/03090560110363364

Levitt, T. (1969). the marketing mode. new York: McGraw-Hill Book Company.

Lumpkin, G., \& Dess, G. (1996). Clarifying the entrepreneurial orientation construct and linking it to performance. Academy of Management Review, 21, 135-172.

Merriam-Webster. (2009). Available at: http://www.merriam-webster.com /dictionary/orientation. Online dictionary

Miller, D. (1983). The correlates of entrepreneurship in three types of firms. Management Science, 29, 770-790.http://dx.doi.org/10.1287/mnsc.29.7.770

Narver, J., \& Slater, S. (1990). The effect of a market orientation on business profitability. Journal of Marketing, 54, 20-35.http://dx.doi.org/10.2307/1251757

Noble, C., Sinha, R., \& Kumar, A. (2002). Market orientation and alternative strategic orientations: a longitudinal assessment of performance implications. Journal of Marketing, 66, 25-39. http://dx.doi.org/10.1509/jmkg.66.4.25.18513

Porter, M. (1985). Competitive Advantage. New York: Free Press.

Porter, M. (1980). Competitive Strategy. New York: Free Press.

Shapiro, B. P. (1988). What The Hell is Market Oriented? Harvard Business Review, 66(6), 119-125.

Sheppard, H. (2011). The Evolution and Conceptualization of Market Orientation: What Managers Ought to Know. Journal of Management Policy and Practice, 12(6). 


\section{Macrothink}

Journal of Management Research ISSN 1941-899X 2013, Vol. 5, No. 1

Sinkula, J., Baker, W., \& Noordewier, T. (1997). A framework for market-based organizational learning: linking values, knowledge, and behavior. Academy of Marketing Science Journal, 25, 305-318.http://dx.doi.org/10.1177/0092070397254003

Webster, F. E. (1988). Rediscovering the Marketing Concept. Business Horizons, 31, 29-39. http://dx.doi.org/10.1016/0007-6813(88)90006-7

Wiklund, J., \& Shepherd, D. (2005). Entrepreneurial orientation and small business performance: a configurational approach. Journal of Business Venturing, 20, 71-91. http://dx.doi.org/10.1016/j.jbusvent.2004.01.001 